\title{
INNOVATIONS AS A BUSINESS RISK IN ENTERPRISES
}

\author{
Jacek WOŹNIAK ${ }^{1 *}$, Zdzisław WOJCIECHOWSKI ${ }^{2}$ \\ ${ }^{1}$ Institute of Organisation and Management, Faculty of Security, Logistics and Management, Military University \\ of Technology in Warsaw; jacekj.wozniak@wat.edu.pl, ORCID: 0000-0001-7592-0109 \\ ${ }^{2}$ Institute of Organisation and Management, Faculty of Security, Logistics and Management, Military University \\ of Technology in Warsaw; zdzislaw.wojciechowski@wat.edu.pl, ORCID: 0000-003-1716-117X \\ * Correspondence author
}

Purpose: Nowadays, the creative industry is a dynamically developing area in the economies of many regions and even whole countries. Enterprises of the creative industry are able to increase the value of life of many people, as well as generate the broadly understood welfare. In this case, it is worth to identify peculiarity of innovative processes and risk management in this kind of enterprises.

Design/methodology/approach: In the article, there is described peculiarity of the creative industry in the national economy in Poland in the area of innovative activities. An analysis of the impact of risk on these activities is presented. The paper presents the results of a survey carried out in four industries that are compatible with the Polish Classification of Activity (advertising, architecture \& urbanity, IT \& software, design). The leading research tool was the CATI questionnaire. To test the statistical significance methods of non-parametric statistics were used.

Findings: On the basis of the research results' analysis, it can be concluded that risk management under the conditions of functioning of enterprises from the creative industry in Poland is not an inherent element of the decision-making processes in the sphere of innovative activities.

Originality/value: The article addresses the issue of managing innovation processes in enterprises of the creative industry - with a particular focus on risk management. This issue has not been sufficiently analysed in the Polish and international scientific literature yet. The article also provides a guidance on how to manage risk in innovative processes in the creative industry.

Keywords: Enterprise, creative industry, innovation process, risk.

Category of the paper: Research paper. 


\section{Introduction}

Nowadays, the creative industry is a dynamically developing area in the economies of many regions and even whole countries, becoming, in some cases, their kind of "showcase". Some examples are, among others, the Polish video game industry, Nordic (mainly Swedish) design, British music industry, or French film industry and the Italian fashion industry. The creative industry, regardless of geographic location, is responsible for increasing the attractiveness of products and services, and thus for adjusting them to the needs of specific market segments and for raising the general quality of people's lives. Therefore, it is important that projects in this industry take into account risk management processes.

The aim of the article is to evaluate innovative activities in the areas of product and process innovations in the context of risk management. The leading research tool was the CATI questionnaire. To test the statistical significance methods of non-parametric statistics were used. The study focused on the commercial activities of enterprises from the creative services subindustry (advertising, architecture \& urbanity, IT \& software, design).

\section{Essence of the creative industry}

The concept of creative industry appeared for the first time in Australia in 1994 with the publication of the report entitled Creative Nation. This document was widely distributed in the UK in 1997 by the establishment of Creative Industries Task Force. The definitions of the creative industry have evolved since that moment, taking on different versions in certain countries (Creative Economy Report, 2008). The Department for Culture, Media and Sport (DCMS) from the UK defines the creative industry as a collection of activities that are retrieved in the creativity, skill and talent of the individuals (creative workers). These kind of "creative competences" and intellectual properties are cumulated over time and serve the creation of wealth and values for the society and the next generation (DCMS, 2001). Often, the functioning of the creative industry is seen through the prism of commercial activities in the strict sense, i.e. the so-called creative enterprises (Mackiewicz, Michorowska, Śliwka, 2009, p. 7). For example, according to R. Kasprzak (2013, p. 47), the creative industry is the area of social services including economic activities aimed at the creation and commercialisation of cultural products and which refers to various organisational forms of business. In turn, the document titled Creative Industries in Berlin. Development and Potential also includes to the creative activities, in addition to the commercial activities, the cultural services funded by the public administration, as well as non-governmental organisations, involved in activities in the area of culture (Creative Industries in Berlin, 2008, p. 5; Lewandowski, Mućk, Skrok, 2010, p. 7). 
Creative activities include both a typical area related to culture and art in the strict sense (i.e. high culture), as well as creation and delivery of consumer goods (i.e. low/popular culture) (Górniak et al., 2013, p. 13). A widely accepted classification (Anand, Croidieu, 2015, pp. 338-342) of activities within the creative industry - developed by DCMS - lists the subindustries as follows (Kasprzak, 2013, p. 36): (1) arts and crafts: performative art, art and antiques market, crafts; (2) creative production: publishing and music, film and video, TV and radio, computer and video games, as well as fashion industries; (3) creative services: advertising, architectural and urban design, software services, design. The basic approach to defining the creative industry in the article is the narrow approach, focusing on the commercial activities.

\section{Peculiarity of innovation processes in the creative industry - selected aspects}

The intensification of activities in the areas of creating, deploying and commercialising innovations concerns various industries and sectors, including the creative industry. This industry, within the present socio-economic conditions of developed countries (though not only), has an increasing importance, which can be shown at least by the value of export of creative goods (Creative Economy Report, 2013, p. 162). The goods created by the widely understood culture allow, on the one hand, for the implementation of the higher-order needs of people in different social groups, and on the other hand, they are no longer luxury goods becoming normal goods. People do not seek substitutes for cultural goods, because they are able to use deals at the highest available level.

The contemporary processes of creation, deployment and commercialisation of innovation in enterprises of the creative industry are carried out on the basis of so-called open innovations, e.g. in network structures (Sopińska, Mierzejewska, 2017). This concept implies the involvement of certain units from the enterprise's environment in the innovative process. K. Poznańska asserts that "the companies using an open innovation model are more focused on the use of the opportunities beyond it. They also do not avoid the reverse situation. They can share their ideas, technologies and processes with other partners" (Poznańska, 2014, p. 155). It is an interesting approach to shape the development of the creative industry and an important reservoir of opportunities related to the implementation of innovative processes and their improvement.

Having regard to the fact that the creative industry is created primarily by micro, small and medium-sized enterprises, increasing the scope of access to external resources and scale of operations seems to be a necessary factor in raising the level of innovativeness. In the creative industry, innovations require an integration of different resources, often not available in a given 
location. Thus, it is necessary to search for resources with the desired market value and create the value chains on a global scale. There can also be observed changes in the behaviour and thinking of people in many countries who want to participate in the creation of innovations this is particularly important in the creative industry, where the customised activities are dominant according to the precise requirements of specific classes of purchasers.

Today, the direction of enterprises from the creative industry on developing breakthrough innovations can still be observed, which can deliver the biggest benefits. This type of innovation is still an important development factor for enterprises, but incorporating them into the innovation system in the creative industry is not currently a leading trend. In practice, these are the capital- and time-consuming innovations, and the financial return on such investments is not fast. According to this, breakthrough innovations, avoiding the effect of promoting the enterprise on the market, are usually treated as a long-term investment, which many enterprises (particularly micro and small ones) cannot afford. Nowadays, there can be observed an opposite trend in the creative industry - enterprises see more and more tangible business benefits in deploying imitations and developing incremental innovations (Niedzielski, 2008, pp. 230-239; Varbanova, 2015, pp. 43-48).

Focusing on the service enterprises, it can be noticed that service innovation is a result of the every activity of an enterprise provided to another party or benefits that do not have a tangible nature, which one of the parties can offer the other (Randhawa, Scerri, 2015). Innovation in the form of service is closely linked to the executor (Campagnolo, Cabigiosu, 2015, pp. 111-112) - each enterprise from the creative industry can provide a similar service innovation in a different way, e.g. the costs of providing the service, the quality of used resources or the completeness and comprehensiveness of the activities performed within the service can be different. Product innovation, in a similar form, may be developed and deployed by different entities, while in the case of service innovation, this is difficult or even impossible. Therefore, it is important to select an appropriate executor of the service innovation. Moreover, service innovations are described by the following features: (1) inability to wide-ranging standardisation of innovative processes; (2) impermanence and a limited patent protection; (3) incorporation of the customer into the innovative process (prosumption); (4) limited redistribution of the results of the innovative process by the customer (D'Emidio, Dorton, Duncan, 2015, pp. 2-8; DeVine, Lal, Zea, 2012, p. 5; Niedzielski, 2008, pp. 231-235).

In conclusion, it should be noted that the trends in innovative activities of enterprises from the creative industry are around the issue of opening businesses on the third parties and using the potential of innovations already developed and deployed in the market. These enterprises are primarily guided - within modern innovative processes - by the rationality and efficiency accounting, as well as put more and more emphasis on the development and commercialisation of innovations in the form of the highly individualised goods. 


\section{Areas of risk management in enterprises from the creative industry}

Nowadays, enterprises from the creative industry are not able to function as autonomous entities (Gandini, Bandinelli, Cossu, 2017, pp. 16-29). Therefore, they interact with units located in their environment - and in terms of innovative activities, they obtain the potential of not only other "creative" enterprises, but also the seemingly "separated" and subject "distant" organisations. An interesting example may be the public sector or non-governmental (nonprofit) entities, who, despite appearances, are very important in stimulating the development of both individual enterprises and the entire creative industry (Varbanova, 2015, pp. 30-33), as well as in determining risk management processes.

The collaboration of the enterprise from the creative industry with stakeholders can be carried out in different problem areas, e.g. financial, technological and technical, relational, cultural, regulatory and market (Wereda, 2015, p. 219 et seq.). Detailed dimensions of cooperation can be seen as a basis for identifying the key risk classes in service enterprises from the creative industry in terms of innovative activities as follows: financial risk (Fleming, 2007, pp. 107-122), personnel risk (Hennekam, Bennett, 2016, pp. 35-38), operational risk (Kembaren, Simatupang, Larso, Wiyancoko, 2014, p. 103), market risk (Patten, 2016, p. 35), regulatory risk (Wojnar, 2016, pp. 281-285; Bilton, 2010, pp. 71-76) and configuration risk (Porfírio, Carrilho, Mónico, 2016, p. 5122).

At this point, it should be noted that the above-mentioned risk classes are only a basic list for innovative processes in the service enterprises of the creative industry. In the enterprises of the creative industry, the leading risk assessment criteria are: operating conditions (e.g. dynamics of an environment), operational actions (e.g. number of errors, efficiency), ergonomics and ecology (e.g. aesthetics, functionality of the innovation, impact on the environment), as well as the ability to implement innovations (e.g. access to know-how) (Knosala, Deptuła, 2018, pp. 89-109, 136-152). The above-mentioned criteria result from the peculiarity of the relationships with an environment, and therefore, the specific criteria should be applied to the relevant classes of stakeholders. Thus, it is necessary here to fit the methodology of risk assessment in relation to the scale and scope of the impact of stakeholders on the innovative activities.

The key issue here is the fact that risk management is not strongly embedded in the peculiarity in managing the enterprises from the creative industry and is based primarily on the calculation of profits and losses. Risk management mainly takes the form of general and "silo" activities, and the risk management process is mainly to identify the core risk factors and to try and neutralise them. Risk management generally has a low level of complexity and integration of activities, and risk is treated as a "bad thing" and not as a chance/development factor. In addition, risk management is within the domain of the business owners and not within all classes of employees - which may hinder the processes of risk identification and evaluation (Galli, 2017, pp. 39-49; Kasiewicz, 2012). 


\section{Empirical studies of risk assessment and its impact on innovation activities in the industry of creative enterprises}

\subsection{Research methodology and specification of the research sample}

The research was conducted in 104 enterprises (large, small, medium and micro), operating in the creative services subindustry, located in 16 voivodships in Poland (Fig. 1). The respondents were the influencers on decision-making in innovative and risk management processes - i.e. business owners or managers responsible for the areas of risk management, relationships with an environment or innovations.

The research tool was a CATI questionnaire, in which respondents (with the use of a 5-degree scale) evaluated the degree of fulfilment of actions in the areas of innovative processes and risk management in their enterprises. The results of the evaluation of $n$ question ( $n=1 \ldots 53$ ), given by the $m$ respondent ( $m=1 \ldots 104)$, were examined via statistical analysis. The calculation was carried out with the use of a Microsoft Excel spreadsheet.

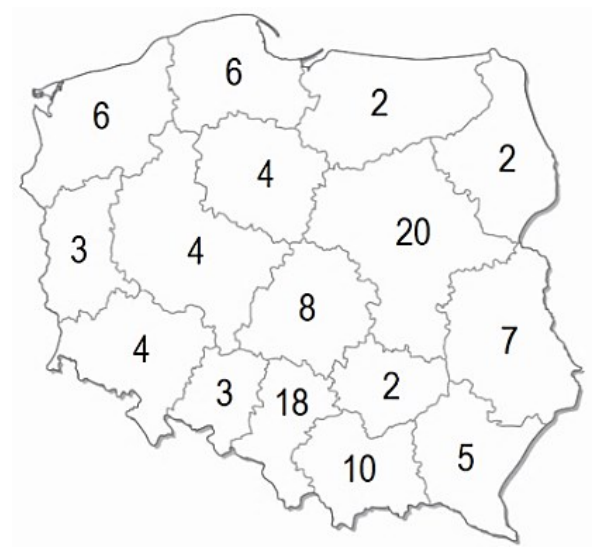

Figure 1. Number of enterprises participating in the survey - in voivodships $(N=104)$. Source: own elaboration.

The aim of the study was to assess innovation activities in terms of product and process innovations (according to: Oslo Manual, 2008, p. 48), in the context of risk management. The main research problem was as follows: Are innovative activities (carried out in the creative industry) assessed through the prism of risk? To justify the research process, the following hypothesis has been defined: Risk management is an integral part of the decision-making process in the area of innovative activities in enterprises of the creative industry.

\subsection{Analysis of the results of empirical research}

An analysis of the research results shows that the dominant value (among the 5-degree scale of rates indicated by respondents) is 3 , both in terms of the implementation of actions in the area of "innovativeness" (13 questions) and "risk" (40 questions) (Tab. 1). 
Table 1.

Distribution of responses (in \%) $(N=104)$

\begin{tabular}{|c|c|c|c|c|c|}
\cline { 2 - 6 } \multicolumn{1}{c|}{} & \multicolumn{5}{c|}{ Rating scale - degree of fulfilment of the action } \\
\hline Area of activity & Lack (1) & Low (2) & Average (3) & High (4) & Full (5) \\
\hline "Innovativeness" & 6.94 & 25.46 & $\mathbf{2 8 . 7 3}$ & 28.5 & 13.41 \\
\hline "Risk" & 7.04 & 23.22 & $\mathbf{3 6 . 6 3}$ & 28.91 & 4.18 \\
\hline
\end{tabular}

Source: own elaboration.

For the assessment of activities in the areas of "innovativeness" and "risk", the average value $(\bar{x})$ and standard deviation value ( $s$ ) were used (Tab. 2), which gave rise to group all activities, as well as indicate the activities assessed at a minimum (min) and maximum (max) level. Table 2 shows that the highest rated activities in the area of "innovativeness" refer to the necessity of engaging executives/owners $(\bar{x}=4.471154)$, with a coefficient of variation $V=15.88 \%$ - small differentiation of rates $\left.{ }^{1}\right)$. The activities rated at the lowest level are:

- provision of external financing $(\bar{x}=2.201923$, with $V=51.56)$,

- need to enable R\&D in innovative processes $(\bar{x}=2.307692$, with $V=41.87 \%)$.

In the area of "risk", the highest rated activities concern:

- application of corrective and/or replacement actions $(\bar{x}=3.336538$, with $V=24.92 \%)$,

- taking into account risk assessment $(\bar{x}=3.865385$, with $V=19.43 \%)$,

- optimising risk for the entire enterprise $(\bar{x}=3.855769$, with $V=17.49 \%)$.

The lowest rated activities are:

- systematic completion of risks repositories $(\bar{x}=2.221154$, with $V=29.40 \%)$,

- creating risk management teams $(\bar{x}=2.355769$, with $V=37.37 \%)$.

The analysis of the results indicates their differentiation, and the rang ordering for the analysed activities in these areas is weak, as these are the bundled ranks, which means a situation in which respondents consider that there is no difference between some of them, because, in fact, one assessment combines at least two activities. Therefore, for further analyses, there should be used such research tools that can clearly respond to a set research problem. For this purpose, in the case of interdependence of data, non-parametric statistical methods were used to test the statistical significance in the survey.

Table 2.

Assessment of activities in the surveyed enterprises $(N=104)$

\begin{tabular}{|c|c|c|c|c|c|c|}
\hline \multirow{3}{*}{$\begin{array}{c}\text { No. of } \\
\text { activity }\end{array}$} & \multicolumn{2}{|c|}{ "Innovativeness" area } & \multicolumn{4}{|c|}{ "Risk" area } \\
\hline & \multirow{2}{*}{$\bar{x}$} & \multirow[b]{2}{*}{$s$} & \multicolumn{2}{|c|}{ Set No. 1} & \multicolumn{2}{|c|}{ Set No. 2} \\
\hline & & & $\bar{x}$ & $s$ & $\bar{x}$ & $s$ \\
\hline 1 & 3.259615 & 1.149041 & 2.923077 & 1.228246 & 3.528846 & 0.69613 \\
\hline 2 & 4.471154 & 0.70994 & 2.865385 & 1.015011 & 3.317308 & 0.861974 \\
\hline 3 & 2.759615 & 0.990197 & 2.423077 & 1.282385 & 2.942308 & 0.879397 \\
\hline 4 & 2.307692 & 0.966195 & 3.028846 & 1.092399 & 3.346154 & 0.707371 \\
\hline 5 & 4.134615 & 0.711319 & 2.355769 & 0.880404 & 2.951923 & 0.805079 \\
\hline
\end{tabular}

${ }^{1}$ If the coefficient of variation is between $0-20 \%$, the diversity of the population is small. If it is in the range between $20-40 \%$, it is said to be a medium diversity of the population. In the case of the range between $40-60 \%$, it is a large variety. When the ratio exceeds $60 \%$, this means that the variation is very large. 
Cont. table 2.

\begin{tabular}{|c|c|c|c|c|c|c|}
\hline 6 & 3.605769 & 0.840923 & 2.913462 & 0.956435 & 3.423077 & 0.771989 \\
\hline 7 & 2.846154 & 0.952964 & 2.788462 & 0.991939 & 2.498634 & 0.790569 \\
\hline 8 & 2.201923 & 0.999191 & 2.971154 & 1.074476 & 2.605769 & 0.896793 \\
\hline 9 & 3.105769 & 1.032654 & 2.990385 & 1.038064 & 2.644231 & 0.799493 \\
\hline 10 & 3.528846 & 0.923866 & 2.903846 & 0.970629 & 3.230769 & 0.883844 \\
\hline 11 & 2.971154 & 0.939497 & 2.519231 & 0.788027 & 2.413462 & 0.662601 \\
\hline 12 & 3.326923 & 0.886165 & 2.634615 & 1.141092 & 3.615385 & 0.658148 \\
\hline 13 & 2.5 & 0.847612 & 2.855769 & 1.065052 & 3.576923 & 0.746413 \\
\hline 14 & & & 2.961538 & 0.97466 & 3.865385 & 0.75115 \\
\hline 15 & & & 3.086538 & 0.976526 & 3.451923 & 0.811086 \\
\hline 16 & & & 2.942308 & 1.113264 & 3.721154 & 0.806006 \\
\hline 17 & & & 2.884615 & 0.851129 & 3.855769 & 0.674332 \\
\hline 18 & & & 3.336538 & 0.831545 & 3.173077 & 0.805832 \\
\hline 19 & & & & & 2.807692 & 0.764211 \\
\hline 20 & & & & & 2.576923 & 0.86678 \\
\hline 21 & & & & & 2.711538 & 0.899548 \\
\hline 22 & & & & & 2.221154 & 0.65295 \\
\hline
\end{tabular}

Source: own elaboration.

The highest ratings

The lowest ratings

To assess the conformity between the ratings of respondents and the bundled ranks for the weak alignments, the Kendall-Smith ( $W$-Kendall) concordance coefficient (1) has been used (Cabała, 2010, p. 43):

$W=\frac{\sum_{j=1}^{n}\left(R j-\frac{m(n+1)^{2}}{2}\right)}{\frac{1}{12} * m^{2}\left(n^{3}-n\right)-m^{*} T}$,

where:

$T=\frac{1}{12} \sum\left(t_{i}^{3}-t_{i}\right)-$ fix for the bundled ranks;

$t_{i}=$ the number of cases within the bundled ranks;

$R_{j}-$ rank of $j$ criterion.

An instance of the bundled ranks determines the specification of the average ranks. An example of averaging them and calculating the fix for the $T_{i}$ bundled ranks (for activities in the area of "innovativeness" in the form of 13 survey questions) can be found in Table 3.

Table 3.

Calculation of average rank and bundled ranks $(N=104)$

\begin{tabular}{|c|c|c|c|c|c|c|c|c|c|c|c|c|c|c|c|c|}
\hline \multirow{9}{*}{$\begin{array}{c}\text { Respondent's } \\
\text { ranks } \\
\text { Average } \\
\text { ranks }\end{array}$} & $m / n$ & 1 & 2 & 3 & 4 & 5 & 6 & 7 & 8 & 9 & 10 & 11 & 12 & 13 & Checksum & $T_{i}$ \\
\hline & 1 & 4 & 4 & 1 & 2 & 4 & 3 & 3 & 3 & 4 & 3 & 2 & 2 & 4 & & \\
\hline & 1 & 11 & 11 & 1 & 3 & 11 & 6.5 & 6.5 & 6.5 & 11 & 6.5 & 3 & 3 & 11 & 91 & 17 \\
\hline & 2 & 4 & 4 & 2 & 1 & 1 & 3 & 1 & 1 & 3 & 4 & 5 & 2 & 2 & & \\
\hline & 2 & 11 & 11 & 6 & 2.5 & 2.5 & 8.5 & 2.5 & 2.5 & 8.5 & 11 & 13 & 6 & 6 & 91 & 9.5 \\
\hline & $\ldots$ & $\ldots$ & $\ldots$ & $\ldots$ & $\ldots$ & $\ldots$ & $\ldots$ & $\ldots$ & $\ldots$ & $\ldots$ & $\ldots$ & $\ldots$ & $\ldots$ & $\ldots$ & & \\
\hline & $\ldots$ & $\ldots$ & $\ldots$ & $\ldots$ & $\ldots$ & $\ldots$ & $\ldots$ & $\ldots$ & $\ldots$ & $\ldots$ & $\ldots$ & $\ldots$ & $\ldots$ & $\ldots$ & & \\
\hline & 103 & 3 & 5 & 3 & 2 & 5 & 2 & 2 & 3 & 3 & 2 & 2 & 4 & 3 & & \\
\hline & 103 & 8 & 12.5 & 8 & 3 & 12.5 & 3 & 3 & 8 & 8 & 3 & 3 & 11 & 8 & 91 & 20.5 \\
\hline
\end{tabular}


Cont. table 3.

\begin{tabular}{|c|c|c|c|c|c|c|c|c|c|c|c|c|c|c|c|c|}
\hline \multirow{4}{*}{$\begin{array}{c}\text { Sum of } \\
\text { Average } \\
\text { ranks for } \\
\boldsymbol{i} \text { activity } \\
\text { Average } \\
\text { of ranks }\end{array}$} & 104 & 4 & 4 & 3 & 1 & 4 & 4 & 4 & 3 & 4 & 3 & 4 & 4 & 2 & & \\
\hline & 104 & 9.5 & 9.5 & 4 & 1 & 9.5 & 9.5 & 9.5 & 4 & 9.5 & 4 & 9.5 & 9.5 & 2 & 91 & 44 \\
\hline & $\boldsymbol{R}_{i}$ & 749.5 & 1155.5 & 596.5 & 435.5 & 1069.5 & 889.5 & 611.5 & 436 & 706 & 855 & 651.5 & 782 & 499 & & $\underset{2272.50}{\sum T_{i}}$ \\
\hline & $\boldsymbol{R}_{j}$ & & & & & & 725.9 & & & & & & & & & \\
\hline
\end{tabular}

Source: own elaboration.

The $W$-Kendall coefficient is expressed on the ordinal scale, assuming a " 0 " value in the absence of compliance and a "1" value for full compliance. In literature, there is proposed the following form of structuring the degree of compliance of the concordance factor: sufficient for the interval 0.20-0.40; good - 0.41-0.60; good plus - 0.61-0.80; very good - 0.81-0.95; as well as perfect - 0.96-1.00 (Stabryła, 2006, p. 185; Stabryła, 2005, p. 106). The values of the concordance coefficient in the survey are contained in Table 4.

Table 4.

$W$-Kendall concordance coefficient in the survey $(N=104)$

\begin{tabular}{|c|c|c|c|}
\cline { 2 - 4 } \multicolumn{1}{c|}{} & Research population & "Innovativeness" & "Risk" \\
\hline W-Kendall concordance coefficient & 0.275715 & 0.348581 & 0.253644 \\
\hline Degree of ranks' compliance & sufficient & sufficient & sufficient \\
\hline
\end{tabular}

Source: own elaboration.

For the assessment of the statistical significance of the concordance rate for the $n>7$ number of criteria, the Chi-square distribution, with $k=n-1$ freedom degrees (2) has been used:

$$
\chi^{2}=\frac{S}{\frac{1}{12} * m n(n+1)-\frac{1}{n-1} * T},
$$

where:

$S$ - the sum of squares of differences of the average sum of the ranks and the sum of the ranks of $j$ test position:

$S=\sum_{j=1}^{k}\left(\sum_{i=1}^{n} x_{i j}-\bar{x}\right)^{2}$

$\bar{x}=\frac{1}{k} \sum_{i=1}^{n} \sum_{j=1}^{k} x_{i j}$ average value of the sum of ranks for all variants;

$x$-assessment of $i$ respondent for $j$ factor.

According to this, for the surveyed issues, the following hypotheses have been stated: $H O$ - between the experts' assessments, there is no enough compliance, and $H 1$ - between the experts' assessments, there is sufficient compliance. The $H 0$ hypothesis is accepted if $\chi^{2}<\chi^{2} k r$, as well as rejected if $\chi^{2}>\chi^{2} k r$ - which means that between experts' assessments, there is a sufficient correlation. The critical value was taken from the Chi-square distribution array. The results are shown in Table 5. 
Table 5.

Value of $\chi^{2}$ statistics and H0 hypothesis verification $(N=104)$

\begin{tabular}{|c|c|c|c|}
\hline & Research population & "Innovativeness" & "Risk" \\
\hline$\chi^{2}$ & 1491.066166 & 435.029448 & 1028.781359 \\
\hline$\chi_{k r}^{2}$ for $k=104, \alpha=0.05$ & \multicolumn{3}{|c|}{128.804} \\
\hline Conclusion: & \multicolumn{3}{|c|}{ H0 hypothesis - rejected, H1 hypothesis - accepted } \\
\hline
\end{tabular}

Source: own elaboration.

The strength of the monotonic relationship between the tested criteria has been specified with the use of the Spearman's average correlation coefficient (3):

$\bar{r}_{s}=\frac{n W-1}{n-1}$.

In literature, the following scale for the strength of correlation is used: $<0.2$ - lack of dependence; 0.2-0.4 - weak dependence; 0.4-0.7 - moderate dependence; 0.7-0.9 - fairly strong dependence, as well as $>0.9$ - very strong dependence. The values of Spearman's average correlation coefficient for the survey are contained in Table 6.

The compliance of respondents' rates in the given industries in accordance with the PKD (i.e. Polish Classification of Activity) classification has been assessed according to the above methodology, and the results are presented in Table 7. The PKD numbering adopted in the survey is as follows: $62.01 . \mathrm{Z}$ - software, $(N=27), 73.11 . \mathrm{Z}$ - advertising agencies $(N=25)$, 71.11.Z - architecture $(N=26)$, as well as 74.10.Z - special designing $(N=26)$.

Table 6.

Value of the Spearman's average correlation coefficient $(N=104)$

\begin{tabular}{|c|c|c|c|}
\cline { 2 - 4 } \multicolumn{1}{c|}{} & Research population & "Innovativeness" & "Risk" \\
\hline$r_{s}$ & 0.268683 & 0.342257 & 0.246398 \\
\hline Assessment & \multicolumn{2}{|c|}{ weak dependence } \\
\hline
\end{tabular}

Source: own elaboration.

For the area of "innovativeness" in the field of activities related to the software, the action relating to enabling $R \& D$ processes in innovative processes has the smallest average value of respondents' ratings. Triggering a high level of executives' involvement has the greatest value. The same situation occurs in the case of advertising agencies. In the architecture area, a need to provide external financing has the smallest average value of respondents' ratings, and the largest value - triggering a high level of executives' involvement. For the activities in the field of special designing, the smallest importance has supporting the product innovations, organisational and/or marketing innovations. The most important is triggering the involvement of managers. 
Table 7.

Compliance assessment of respondents' rates for particular industries according to the PKD numbers

\begin{tabular}{|c|c|c|c|c|c|c|c|c|c|}
\hline & \multicolumn{2}{|c|}{ PKD: 62.01.Z } & \multicolumn{2}{|c|}{ PKD: 73.11.Z } & \multicolumn{2}{|c|}{ PKD: 71.11.Z } & \multicolumn{2}{|c|}{ PKD: 74.10.Z } \\
\hline & & I & II & I & II & I & II & I & II \\
\hline $1 \mathrm{a}$ & $\bar{x} \mathrm{~min} / \mathrm{s}$ & $\begin{array}{c}2.5555 / \\
1.1875\end{array}$ & $\begin{array}{l}2.2222 / \\
3.7407\end{array}$ & $\begin{array}{c}1.88 / \\
0.8812\end{array}$ & $\begin{array}{c}2 / \\
0.7071\end{array}$ & $\begin{array}{l}1.4230 / \\
0.7575\end{array}$ & $\begin{array}{c}2.2692 / \\
1.0023\end{array}$ & $\begin{array}{l}2.3076 / \\
0.7883\end{array}$ & $\begin{array}{c}2.0384 / \\
1.1482\end{array}$ \\
\hline $\begin{array}{l}1 \\
b\end{array}$ & $\bar{x} \max / s$ & $\begin{array}{c}4.5555 / \\
0.9622\end{array}$ & $\begin{array}{c}2 / \\
3.7407\end{array}$ & $\begin{array}{c}4.36 / \\
0.7571\end{array}$ & $\begin{array}{c}3.72 / \\
0.8906\end{array}$ & $\begin{array}{c}4.4389 / \\
0.7071\end{array}$ & $\begin{array}{l}3.9615 / \\
0.4454\end{array}$ & $\begin{array}{l}4.4615 / \\
0.7605\end{array}$ & $\begin{array}{c}4.0769 / \\
0.2717\end{array}$ \\
\hline $2 a$ & $W$-Kendall & 0.3360 & 0.2344 & 0.3760 & 0.2475 & 0.4932 & 0.3260 & 0.3658 & 0.3593 \\
\hline $\begin{array}{l}2 \\
b\end{array}$ & $\begin{array}{c}\text { Compliance } \\
\text { degree }\end{array}$ & sufficient & sufficient & sufficient & sufficient & good & sufficient & sufficient & sufficient \\
\hline $3 a$ & $\chi^{2}$ & 108.8641 & 246.8851 & 112.8044 & 241.3771 & 153.8916 & 330.62207 & 114.1444 & 364.4074 \\
\hline $\begin{array}{l}3 \\
b\end{array}$ & $\begin{array}{c}\chi_{\mathrm{kr}}^{2} \text { for } \\
k=\text { according } \\
\text { to the No. } \\
\text { of PKD, } \\
\alpha=0.05\end{array}$ & \multicolumn{2}{|c|}{40.1133} & \multicolumn{2}{|c|}{37.6525} & \multicolumn{2}{|c|}{38.8851} & \multicolumn{2}{|c|}{38.8851} \\
\hline $3 c$ & Conclusion & \multicolumn{8}{|c|}{ HO hypothesis - rejected, H1 hypothesis - accepted } \\
\hline $4 a$ & $\begin{array}{l}- \\
r_{s}\end{array}$ & 0.3104 & 0.2050 & 0.3500 & 0.2162 & 0.4729 & 0.2991 & 0.3404 & 0.3337 \\
\hline $4 b$ & Dependence & weak & weak & weak & weak & moderate & weak & weak & weak \\
\hline
\end{tabular}

where: I - "innovativeness"; II - "risk"

Source: own elaboration.

For the "risk" area, in terms of activities linked to software, the development and systematic completion of the risk repository has the smallest importance for respondents, and the largest importance - enabling risk assessment processes in the innovative processes. In advertising agencies, the development and completion of the risk repository has the lowest rating, and the highest rating - risk optimisation from the point of view of the entire enterprise. For entities established in the architecture industry, the involvement of at least three decisionmaking levels in risk management has the smallest importance. The most important activity is to optimise risk. The same situation occurs in the field of special designing.

\section{Conclusions}

In times of crisis and increasing competition, each type of innovation is a chance for survival in the market. However, investments carry a certain risk that is associated both with the process of innovation development, as well as their commercialisation and deployment. The sine qua non condition is here an analysis of the impact of risk on the innovation activities, because in enterprises - especially from the creative industry - the possible changes in the conditions of innovative processes must be taken into account.

The article presents the concept of assessment of the basic actions taken by enterprises of the creative services subindustry in Poland in the implementation of innovative processes and risk management. A statistical analysis of the survey results has indicated that certain actions have unequal effects on innovation and risk areas. Thus, in the study, there have been identified 
the activities that, in the assessment of the respondents' rates, achieved the highest and lowest values with the use of the 5-degree (Likert) scale.

On the basis of the research results' analysis, it can be concluded that risk management under the conditions of functioning of enterprises from the creative industry in Poland is not an inherent element of the decision-making processes in the sphere of innovative activities, because, in principle, risk management is carried out in the primary/simplified, as well as "accidental" and "occasional", form. However, entrepreneurs should strive to increase the scope of risk management, with particular emphasis on the risk assessment in the carried out innovative activities, because it may increase the level of effectiveness and efficiency of these processes, while increasing the value provided to the internal and external stakeholders. This seems to be a necessary approach, mainly due to the fact that, in conditions of the Polish economy, the creative industry is becoming "stronger" economically and - in its interior is increasing the level of competition between different enterprises.

\section{Acknowledgements}

The authors would like to thank Centrum Badań Marketingowych INDICATOR (Poland).

\section{References}

1. Anand, N., and Croidieu, G. (2015). Niches, Genres, and Classifications in the Creative Industries. In: C. Jones, M. Lorenzen, and J. Sapsed (Eds.), The Oxford Handbook of Creative Industries (pp. 327-347). Oxford: Oxford University Press.

2. Bilton, Ch. (2010). Polityka kreatywności. In: A. Gwóźdź (Ed.), Od przemysłów kultury do kreatywnej gospodarki (pp. 64-78). Warszawa: Narodowe Centrum Kultury.

3. Cabała, P. (2010). Zastosowanie współczynnika konkordancji w pomiarze zgodności ocen ekspertów. Przegląd Statystyczny, LVII (2-3), 36-52.

4. Campagnolo, D., and Cabigiosu, A. (2015). Innovation, Service Types, and Performance in Knowledge Intensive Business Services. In: R. Agarwal, W. Selen, G. Roos, and R. Green (Eds.), The Handbook of Service Innovation (pp. 109-121). London: Springer-Verlag.

5. Creative Economy Report (2008). New York: United Nations Conference on Trade and Development, United Nations Development Programme.

6. Creative Economy Report (2013). Special edition: Widening local development pathways. New York: United Nations/UNDP/UNESCO.

7. Creative Industries in Berlin. Development and Potential (2008). Berlin. 
8. Creative Industries Mapping Document: Background (2001). London: Department for Culture, Media and Sport. Retrieved from https://www.gov.uk/government/uploads/ system/ uploads/attachment_data/file/183544/2001part1-forew ord2001.pdf, 05.07.2016.

9. D'Emidio, T., Dorton, D., and Duncan, E. (2045). Service innovation in a digital world. McKinsey Quarterly, February. Retrieved from https://www.mckinsey.com/businessfunctions/operations/our-insights/service-innovation-in-a-digital-world\#, 15.03.2017.

10. DeVine, J., Lal, S., and Zea, M. (2012). The human factor in service design. McKinsey Quarterly, January. Retrieved from https://www.mckinsey.com/business-functions/ operations/our-insights/the-human-factor-in-service-design, 12.16.2018.

11. Fleming, T. (2007). Investment and funding for creative enterprises in the UK. In: C. Henry (Ed.), Entrepreneurship in the creative industries. An international perspective (pp. 107-125). Cheltenham: Edward Elgar Publishing.

12. Galli, B.J. (2017). Risk Management in Project Environments: Reflection of the Standard Process. The Journal of Modern Project Management, 6(2), 40-49.

13. Gandini, A., Bandinelli, C., and Cossu, A. (2017). Colaborating, Competing, Co-working, Coalescing: Artists, Freelancers and Social Entrepreneurs as the 'New Subjects' of the Creative Economy. In: J. Graham, and A. Gandini (Eds.), Collaborative Production in the Creative Industries (pp. 15-32). London: University of Westminster Press.

14. Górniak, J. et al. (2013). Bilans kompetencji: Wybrane segmenty branży kreatywnej. Kraków. Retrieved from www.krakow.pl/zalacznik/71487, 21.08.2016.

15. Hennekam, S., and Bennett, D. (2016). Self-Management of Work in the Creative Industries in the Netherlands. International Journal of Arts Management, 19(1), 31-41.

16. Kasiewicz, S. (ed.). (2012). Strategie przedsiębiorstw i zarzadzanie ryzykiem $w$ warunkach kryzysu gospodarczego. Gdańsk: Instytut Badań nad Gospodarką Rynkową.

17. Kasprzak, R. (2013). Przemysty kreatywne w Polsce. Warszawa: Kamon Consulting.

18. Knosala, R., and Deptuła, A.M. (2018). Ocena ryzyka wdrażania innowacji. Warszawa: PWE.

19. Lewandowski, P., Mućk, J., and Skrok, Ł. (2010). Znaczenie gospodarcze sektora kultury. Wstęp do analizy problemu. Raport końcowy. Warszawa: Instytut Badań Strukturalnych.

20. Mackiewicz, M., Michorowska, B., and Śliwka, A. (2009). Analiza potrzeb i rozwoju przemysłów kreatywnych. Warszawa. Retrieved from http://nck.pl/media/study/analiza_pot rzeb_i_rozwoju_przemysw_kreatywnych.pdf, 01.08.2016.

21. Niedzielski, P. (2008). Zarządzanie innowacjami w przedsiębiorstwach usługowych. In: B. Filipiak, and A. Panasiuk (Eds.), Przedsiębiorstwo ustugowe (pp. 224-249). Warszawa: PWN.

22. Oslo manual (2008). Podręcznik Oslo: Zasady gromadzenia i interpretacji danych dotyczacych innowacji. Warszawa: Ministerstwo Nauki i Szkolnictwa Wyższego.

23. Patten, T. (2016). Creative? "Entrepreneur?" - Understanding the creative industries entrepreneur. Artivate: A Journal of Entrepreneurship in the Art, 5(2), 23-42. 
24. Porfírio, J.A., Carrilho, T., and Mónico, L.S. (2016). Entrepreneurship in different contexts in cultural and creative industries. Journal of Business Research, 69, 5117-5123.

25. Poznańska, K. (2014). Sieci współpracy a innowacyjność przedsiębiorstw. In: A. Sopińska, and S. Gregorczyk (Eds.), Granice strukturalnej złożoności organizacji (pp. 151-160). Warszawa: Szkoła Główna Handlowa.

26. Randhawa, K., and Scerri, M. (2015). Service Innovation: A Review of the Literature. In: R. Agarwal, W. Selen, G. Roos, and R. Green (Eds.), The Handbook of Service Innovation (pp. 27-51). London: Springer-Verlag.

27. Sopińska, A., and Mierzejewska, W. (2017). Otwarte innowacje produktowe realizowane przez przedsiębiorstwa działające w Polsce. Podejście zasobowe. Warszawa: Szkoła Główna Handlowa.

28. Stabryła, A. (2005). Zarzadzanie strategiczne w teorii i praktyce firmy. Warszawa: PWN.

29. Stabryła, A. (2006). Zarzadzanie projektami ekonomicznymi i organizacyjnymi. Warszawa: PWN.

30. Varbanova, L. (2015). Zarzadzanie strategiczne w kulturze. Warszawa: Narodowe Centrum Kultury.

31. Wereda, W. (2015). Orientation towards trust and building relationships with stakeholders in the organization. Prace Naukowe Uniwersytetu Ekonomicznego we Wroctawiu, $376,216-232$.

32. Wojnar, K. (2016). Polska klasa kreatywna. Warszawa: Narodowe Centrum Kultury. 